been engaged, among other activities, as consulting metallurgist to the Air Ministry, the Association of Drop Forgers and Stampers, and various motor firms in the Birmingham district. In addition, he has written extensively on metallurgical subjects. The creation of the chair has been welcomed by many leading industrialists.

\section{Chemistry at University College, Leicester: Prof. L. Hunter}

As a consequence of the recognition of University College, Leicester, by the University Grants Committee, the College Council is proceeding to strengthen the teaching staff by the appointment of professors and additional lecturers. Among a number of appointments is that of Dr. L. Hunter to the chair of chemistry. That chemistry should be chosen for one of the first professorships to be established at Leicester is a tribute to Dr. L. Hunter's work as head of the Chemistry Department. Appointed in 1925 to found the Department, Dr. Hunter devoted his first years in Leicester to establisbing and consolidating it. Even during those difficult years, and working under a heavy burden of teaching, he never lost sight of the value and importance of research work in any virile teaching department. In translating this ideal into a reality, Dr. Hunter met many difficulties, not the least being the lack of postgraduate scholarships in so young a college. Surmounting these in many novel ways, Dr. Hunter succeeded in establishing a vigorous and steadily growing research school which consisted, immediately prior to the War, of some ten post-graduate research workers. In this work he was loyally supported by his first assistant, Dr. A. Hickling, who is now lecturer in electrochemistry in the University of Liverpool. Even during the difficult years of war, Dr. Hunter's department maintained a steady though reduced output of original work. Dr. Hunter and his co-workers have made important contributions to the chemistry of the hydrogen bond, particularly as it concerns molecular association and tautomerism, and to the chemistry of chelate metallic derivatives of organic compounds. Coming to Leicester from the University College of North Wales, Bangor, he was versed in the traditions of the late Prof. Kennedy Orton's school of chemistry, and his earlier published work concerned the use of chloroamines in the stepwise halogenation of organic compounds.

\section{Exhibition of German Aeronautical Developments}

THE exhibition of German aeronautical developments, with which the Science Museum, South Kensington, is re-opened, is the result of the great interest taken in a much larger one held at the Royal Aircraft Establishment, Farnborough, during the autumn of 1945. This was confined to invited guests, for obvious reasons, and although these invitations were very widely distributed it was felt that there was still a number of students of aeronautics, in its various aspects, who could profit by it. Limitation of space has necessitated reducing the exhibits, especially the complete aircraft, but as wide a choice in types as possible has been made. Many of the exhibits are sectioned and shown in the 'exploded' form, liberally supplied with explanatory show cards. There are a few exhibits of British work by way of comparison, and an excellent display of photographs, arranged comparatively, German and British.

The aircraft range from gyro-controlled kites, pilotless aircraft, rockets, to the small fighter aircraft.
The engine section has various types of piston engines, and a comprehensive display of gas turbines and jet propulsion units in several forms. Instruments and general equipment occupy some of the galleries, and there is a special display of aireraft armament. The general layout of the exhibition is well thought out, and it should be of great help to the student of aeronautics, who has necessarily not had the opportunity of keeping abreast of the developments in the many different aspects of the science during the war period. A catalogue is available that is not only a guide but also contains much technical information supplementing that given on the show cards. The catalogue invites further inquiries from anyone genuinely interested, which will be answered, so far as further data is available, by the Director, Royal Aircraft Establishment, South Farnborough, Hants.

\section{'Flavazole', an Effective New Antiseptic}

YET another new series of compounds has been added to the growing list of antiseptics. Prof. J. MeIntosh and his collaborators (Lancet of July 28, p. 97) report upon their trials of 'Flavazole', which is a chemical combination, in equimolecular proportions, of sulphathiazole and proflavine base. This represents a new type of acridine compound, which has been introduced by the research laboratories of Messrs. Boots Pure Drug Co., Ltd., and it is claimed to be an advance on the mixtures of one part of proflavine and 99 parts of sulphathiazole, widely used in powder form in the Army and in industry for the first-aid treatment of wounds. These new compounds are neutral or slightly alkaline in solution and are less irritant than their acridine components. In vitro tests have shown that they "have lost none of the bacteriostatic powers of their components". Comparison of the action of 'Flavazole', sulphathiazole and proflavine upon "all types of organisms likely to be found in wounds" (including the Clostridia which cause gas gangrene) shows that the bacteriostatic power of 'Flavazole' is greater than that of either of its components, especially against Gram-negative bacilli. It has slightly more activity against $P$ seudomonas pyocyanea and Proteus.

Clinical trials of 'Flavazole' have shown that it can be safely used in the conjunctival sac and in any infected cavity as a wound antiseptic. Used as a powder composed of 2 per cent 'Flavazole' and 98 per cent of sulphathiazdle, it will control mixed infections in wounds. Dusting with this powder led to the disappearance of bacteria within three days. The severe test of treatment in a spinal unit of pressure sores and other wounds which were heavily infected with pyogenic cocci and Gram-negative bacilli showed that 'Flavazole' greatly reduced these infections. 'Flavazole' is not irritating, and is safer than proflavine. The dilution of penicillin with the powder just mentioned provides "a highly-potent antibacterial power with a wide range of activity against all bacteria likely to be found in wound sepsis".

\section{Conference on Fundamental Particles and Low Temperature Physics}

Tне Physical Society, in collaboration with the Cavendish Laboratory, is holding a conference at Cambridge under the combined title of "Funda. mental Particles" and "Low Temperature Physics" during July 22-27. One day of the conference is to be devoted to the formal opening of the new Austin Wing of the Cavendish Laboratory, and to lectures 